-.-Communication-

\title{
High Current Density Solid Polymer Electrolyte Water Electrolysis
}

\author{
Yasuo NISHIMURA*, Kazuaki YASUDA, Zyun SIROMA and Kinji ASAKA
}

Received June 23, 1997 ; Accepted September 2, 1997

\section{INTRODUCTION}

Solid polymer electrolyte water electrolysis is a clean and high efficient energy technology for hydrogen production from water of an abundantly available resource by using non-fossil fuel energy resources. It is one of the candidates for environmentally benign energy technologies not only for the utilization of $\mathrm{H}_{2}$ as energy carrier but also for the chemical fixation of $\mathrm{CO} 2$.

Solid polymer electrolyte water electrolysis is the method in which an electrocatalyst-membrane composite is used and pure water is supplied to the electrodes and electrolyzed. The advantages of this system are summarized as follows.

1) High energy efficiency.

2) High current density.

3) Pure water electrolysis.

4) High purity of hydrogen.

5) Good response to the change of load.

However, solid polymer electrolyte water electrolysis system has a disadvantage in its initial cost. In order to overcome this disadvantage, an enlargement of hydrogen production performance was needed. Thus a target specification of current density was set at $200 \mathrm{~A} / \mathrm{dm}^{2}(10$ times as large as that of commercialized alkaline electrolyzer) and research and development of the material have been done. Recently, durability tests with $80 \mathrm{~cm}^{2}$ scale cells over 4 years had been done and a test plant with $500 \mathrm{~cm}^{2}$ scale cells with $2 \mathrm{Nm}^{3} /$ h productivity had been demonstrated by Takenaka and Kawami.") And a cost estimation of this type electrolyzer had been done by Uehara in comparison with that of alkaline one.?

Even though this type electrolyzer has such high Department of Energy and the Environment Osaka National Research Institute, AIST, MITI, JAPAN

(1-8-31, Midorigaoka, Ikeda, Osaka, 563, Japan) Key Words: Water Electrolysis, Solid Polymer Electrolyte performances, the maximum performance in high current density has not been checked yet. In this paper, we have tried the performance over $10 \mathrm{~A} /$ $\mathrm{cm}^{2}$ with $10 \mathrm{~cm}^{2}$ scale cell.

EXPERIMENTAL

Nafion $117^{\otimes}$ (DuPont) $(\mathrm{EW}=1100$, thickness $=$ $0.18 \mathrm{~mm}$ ) was used as solid polymer electrolyte. Electrode-membrane composite, Pt / Membrane / $\mathrm{Pt}$, Ir was prepared by chemical plating method. ${ }^{1}$ Platinum plated titanium fiber composite was used as an anodic current supplier. As a cathodic current supplier, carbon composite was used. Apparent electrode surface area was $10 \mathrm{~cm}^{2}$.

At an operation of electrolyzer, water was supplied at only the anodic side. Temperature of the electrolysis cell was monitored at the inlet and the outlet of the anodic compartment. Water electrolyzer was operated at around $80^{\circ} \mathrm{C}$ of temperature. During a high current density operation up to $13 \mathrm{~A} / \mathrm{cm}^{2}$, water was supplied by free circulation with gas lift without a pump. For measurement of IR drop, current interruption method was carried out up to $5 \mathrm{~A} / \mathrm{cm}^{2}$ by forced water circulation with a pump. In order to estimate the electro-osmosis of water accompanied with a proton from the anodic side to the cathodic side, the amount of water transport was measured at the cathodic side during the water electrolysis operation.

\section{RESULTS AND DISCUSSION}

Performance of electrolyzer up to $13 \mathrm{~A} / \mathrm{cm}^{2}$ of current density by free water circulation with gas lift is shown in Fig. 1. Water temperatures at the inlet and the outlet were $79,80^{\circ} \mathrm{C}$ at $3 \mathrm{~A} / \mathrm{cm}^{2}, 76$, $80{ }^{\circ} \mathrm{C}$ at $5 \mathrm{~A} / \mathrm{cm}^{2}, 76,87^{\circ} \mathrm{C}$ at $10 \mathrm{~A} / \mathrm{cm}^{2}$ and 63,86 ${ }^{\circ} \mathrm{C}$ at $13 \mathrm{~A} / \mathrm{cm}^{2}$, respectively. Cell voltage was 5.0 $\mathrm{V}$ and energy efficiency was $25 \%$ at $13 \mathrm{~A} / \mathrm{cm}^{2}$. (For the estimation of energy efficiency, a following formula and $\Delta \mathrm{G}$ base were used and gas purity was taken as $100 \%$.) 


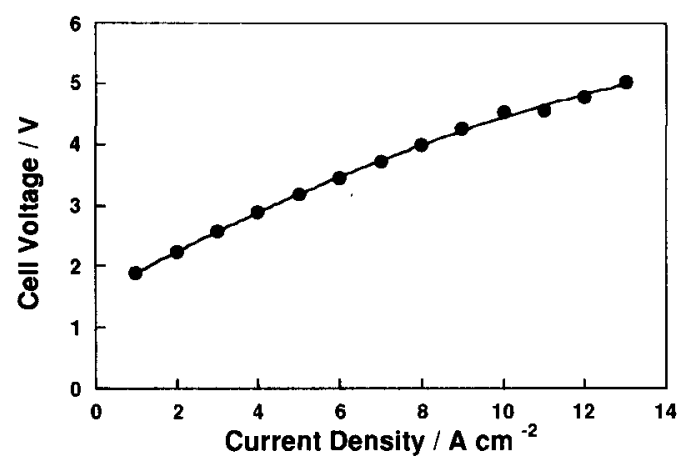

Fig. 1. Cell performance for high current densily water electrolysis

The shape of the line was convex and sudden increase of cell voltage with current density was not observed even at around $10 \mathrm{~A} / \mathrm{cm}^{2}$. Thus it is thought that water supply at the anodic side was sufficient even at around $10 \mathrm{~A} / \mathrm{cm}^{2}$. Over $13 \mathrm{~A} /$ $\mathrm{cm}^{2}$, the cell voltage was unstable. It was difficult to run the electrolyzer by free water circulation at higher current density than $13 \mathrm{~A} / \mathrm{cm}^{2}$.

In order to check the composition of cell voltage, IR drop was measured by current interruption method in the range from $1 \mathrm{~A} / \mathrm{cm}^{2}$ to $5 \mathrm{~A} / \mathrm{cm}^{2}$ as shown in Fig. 2. Temperatures at the inlet and the outlet were $79,81{ }^{\circ} \mathrm{C}$ at $3 \mathrm{~A} / \mathrm{cm}^{2}$ and $78,80^{\circ} \mathrm{C}$ at 5 $\mathrm{A} / \mathrm{cm}^{2}$, respectively. Temperature difference between at the inlet and at the outlet for a free water circulation system was larger than that for a forced water circulation system. With increase of current density, IR drop and cell voltage increased almost linearly. In this range of current density, about $90 \%$ of the increase of the cell voltage was due to the increase of IR drop. At $5 \mathrm{~A} / \mathrm{cm}^{2}$ of current density, the ratio of IR drop to the cell voltage was $34 \%$. Thus, it was shown that the internal resistance of the cell affects to the cell voltage severely at a high current density run.

Water in the membrane plays an important role for ionic conduction in this type membrane. ${ }^{3)}$ In this water electrolysis system, electroosmosis of water accompanied with proton from the anodic side to the cathodic side was observed as shown in Fig. 3. The line was straight and went through zero point. This result showed that the amount of water per proton did not change with current density in the range from $1 \mathrm{~A} / \mathrm{cm}^{2}$ to $10 \mathrm{~A} / \mathrm{cm}^{2}$. The number of water molecules accompanied with a proton was 3.6-3.7 which was estimated from the slope of the

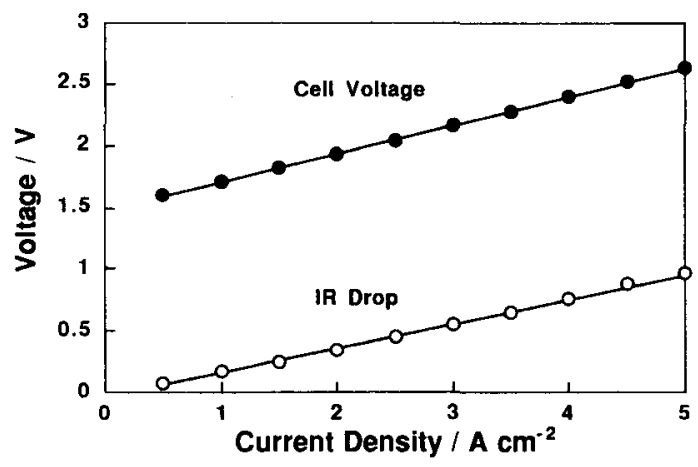

Fig. 2. Ccll voltage and IR drop of high current density water clectrolysis cell

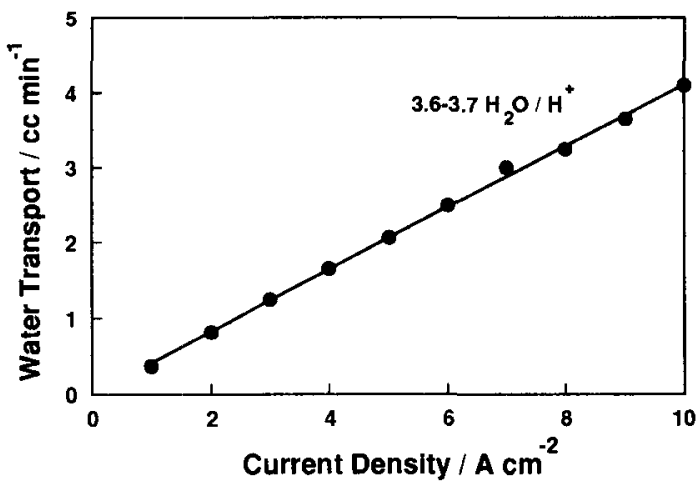

Fig. 3. Water transport with proton through membrane

line. Even at high current density of $10 \mathrm{~A} / \mathrm{cm}^{2}$, water supply to the membrane seemed to be sufficient to keep ionic conductivity. It was thought that this result was concerned to the linearity of the change of IR drop with current density. CONCLUSION

High current density water electrolysis using electrocatalyst-solid polymer electrolyte membrane composite was tried at $13 \mathrm{~A} / \mathrm{cm}^{2}$ by free anodic water circulation with gas lift. Even though cell voltage was high at $13 \mathrm{~A} / \mathrm{cm}^{2}$ of high current density, this demonstration would shed light to further development for hydrogen energy system.

\section{References}

1) H. TAKENAKA, Proceedings of International Hydrogen and Clean Energy Symposium '95, p. 165 (1995).

2) I. UEHARA, H. TANAKA, K. OGURO, H. TAKENAKA, M. KATO, S. MAEZAWA, Proceedings of the 10th World Hydrogen Energy Conference, Cocoa Beach, Florida, p. 607 (1994). 3) J.T.HINATSU, M.MIZUHATA, H. TAKENAKA, J. Electrochem. Soc., 141, 1493 (1994). 